\title{
Communication \\ Detection of Tioman Virus in Pteropus vampyrus Near Flores, Indonesia
}

\author{
Susan M. Tsang ${ }^{1,2,3,4}{ }^{\mathbb{D}}$, Dolyce H. W. Low ${ }^{5,6}$, Sigit Wiantoro ${ }^{7}$, Ina Smith ${ }^{8}$, Jayanthi Jayakumar ${ }^{5}$, \\ Nancy B. Simmons ${ }^{1}$ (D), Dhanasekaran Vijaykrishna ${ }^{9}$, David J. Lohman ${ }^{2,3,4}$ and Ian H. Mendenhall ${ }^{5,10, *} \mathbb{D}$
}

Citation: Tsang, S.M.; Low, D.H.W.; Wiantoro, S.; Smith, I.; Jayakumar, J.; Simmons, N.B.; Vijaykrishna, D.; Lohman, D.J.; Mendenhall, I.H. Detection of Tioman Virus in Pteropus vampyrus Near Flores, Indonesia. Viruses 2021, 13, 563. https:/ /doi. org/10.3390/v13040563

Academic Editor: Peng Zhou

Received: 27 January 2021

Accepted: 15 March 2021

Published: 26 March 2021

Publisher's Note: MDPI stays neutral with regard to jurisdictional claims in published maps and institutional affiliations.

Copyright: (c) 2021 by the authors. Licensee MDPI, Basel, Switzerland. This article is an open access article distributed under the terms and conditions of the Creative Commons Attribution (CC BY) license (https:// creativecommons.org/licenses/by/ $4.0 /)$.
1 Division of Vertebrate Zoology, American Museum of Natural History, New York, NY 10024, USA; stsang@amnh.org (S.M.T.); simmons@amnh.org (N.B.S.)

2 Zoology Division, National Museum of Natural History, Manila 1000, Philippines; dlohman@ccny.cuny.edu

3 Ph.D. Program in Biology, Graduate Center, City University of New York, New York, NY 10016, USA

4 Biology Department, City College of New York, City University of New York, New York, NY 10031, USA

5 Programme in Emerging Infectious Diseases, Duke-National University of Singapore Medical School, Singapore 169857, Singapore; dolyce.low@u.nus.edu (D.H.W.L.); jayanthi.jayakumar@duke-nus.edu.sg (J.J.)

6 Graduate School for Integrative Sciences and Engineering, National University of Singapore, Singapore 119077, Singapore

7 Museum Zoologicum Bogoriense, Research Center for Biology, Indonesian Institute of Sciences, Cibinong, West Java 16911, Indonesia; wiantoro@gmail.com

8 Health and Biosecurity, The Commonwealth Scientific and Industrial Research Organization, Black Mountain, ACT 2601, Australia; Ina.Smith@csiro.au

9 School of Public Health, Li Ka Shing Faculty of Medicine, The University of Hong Kong, Hong Kong, China; veej@hku.hk

10 SingHealth Duke-NUS Global Health Institute, SingHealth Duke-NUS Academic Medical Centre, Singapore 168753, Singapore

* Correspondence: ian.mendenhall@duke-nus.edu.sg

Abstract: Diverse paramyxoviruses have coevolved with their bat hosts, including fruit bats such as flying foxes (Chiroptera: Pteropodidae). Several of these viruses are zoonotic, but the diversity and distribution of Paramyxoviridae are poorly understood. We screened pooled feces samples from three Pteropus vampyrus colonies and assayed tissues, rectal swabs, and oral swabs from 95 individuals of 23 pteropodid species sampled at 17 sites across the Indonesian archipelago with a conventional paramyxovirus PCR; all tested negative. Samples from 43 individuals were screened with next generation sequencing (NGS), and a single Pteropus vampyrus collected near Flores had Tioman virus sequencing reads. Tioman virus is a bat-borne virus in the genus Pararubulavirus with prior evidence of spillover to humans. This work expands the known range of Tioman virus, and it is likely that this isolated colony likely has sustained intergenerational transmission over a long period.

Keywords: bat-borne virus; flying foxes; Indonesia; next generation sequencing; paramyxovirus; Pteropodidae

\section{Introduction}

Bats (Mammalia: Chiroptera) are unique animals with ecological, immunological, and behavioral attributes that set them apart from other mammalian orders [1]. Bats comprise approximately one-fifth of all extant mammal species and are the only taxon capable of powered flight [2]. Many species roost in large colonies, some of which number more than one million individuals [3], and many bats are unusually long-lived in relation to their body size [4]. Bats are natural reservoirs for a diverse pool of viruses, including several that are zoonotic and able to infect humans [5]. These emerging zoonotic viruses typically originate from areas with relatively high mammal diversity, high human population density, and anthropogenic disturbance [6,7]. Deforestation, forest fragmentation, and agricultural intensification can alter wild habitats, leading to increased opportunities for virus spillover from bats to humans [8,9]. 
Bats host numerous genera in the virus family Paramyxoviridae, and proactive discovery of novel paramyxoviruses and their natural reservoir host species benefits public health [10]. Paramyxoviruses are single-stranded, negative-sense RNA viruses in the order Mononegavirales. The genomes of paramyxoviruses are between 15,000-20,000 nucleotides in length, and all have nucleocapsid, phosphoprotein, matrix, fusion, attachment, and large polymerase genes [11]. The large polymerase gene $(\mathrm{L})$ is conserved within Paramyxoviridae and is therefore a target for diagnostic, family-level PCR primers [12]. This diverse virus family infects mammals, birds, reptiles and fish, and its four subfamilies include medically important species [13]. The subfamily Avulavirinae infects birds and includes the Newcastle disease virus that infects domestic poultry, while the subfamily Metaparamyxovirinae consists of a single species that infects fish. The subfamily Orthoparamyxovirinae includes several viral genera, including Morbillivirus (canine distemper virus and measles virus), Respirovirus (human parainfluenza viruses 1 and 3), and Henipavirus (Hendra virus and Nipah virus) [11]. The remaining subfamily Rubulavirinae includes the human parainfluenza viruses 2 and 4, mumps virus, and several recently discovered bat-borne paramyxovirus such as Achimota virus, Hervey pararubulavirus, Teviot virus, Menangle virus, Sosuga virus, and Tioman virus [14,15].

Flying foxes in the genera Pteropus and Acerodon include the world's largest bats (forearm size $>89 \mathrm{~mm}$ and body mass up to $1600 \mathrm{~g}$ ) and with 70 species, they constitute over a third of all species in the family Pteropodidae $[16,17]$. Indonesia is home to about a third of all flying fox species (21 Pteropus spp. and 3 Acerodon spp.), yet only a handful of studies have explored in detail their coevolutionary and ecological histories with viruses [10]. Most flying foxes are declining throughout Indonesia due to hunting, land conversion resulting in loss of roosting or foraging sites, or the combination of both [18]. As a result of this encroachment, many flying foxes have often been pushed to live at the edges of human settlements or in small refugia in a mosaic of developed landscapes $[19,20]$, leading to an increased probability of transmission; however, no bat-borne zoonotic spillovers having been identified in Indonesia to date.

Pteropodid bats-particularly flying foxes-have received significant attention from virologists because they are natural reservoirs of Hendra virus and Nipah virus [21]. Such surveys are especially critical in understudied tropical regions with potentially high levels of human-bat contact, such as insular Southeast Asia. To better understand viral diversity in flying foxes across the Indonesian archipelago, we used Illumina sequencing to screen tissue samples collected for a project aimed at understanding the molecular phylogeography of Pteropus [22], in addition to testing both fecal samples and tissues with a family-specific paramyxovirus PCR.

\section{Materials and Methods}

Tissue samples, rectal swabs, and oral swabs were obtained from wild, adult individuals in Indonesia and were captured from 17 sites throughout Indonesia using either mist nets or traditional hunting methods over the course of 2012-2014 (Figure 1) [19]. We sampled 95 individuals from 23 species, obtaining a total of 262 samples that included multiple sample types from each individual (Table 1).

Samples were collected from nine species of wild-caught flying foxes (Acerodon celebensis, A. mackloti, Pteropus alecto, P. chrysoproctus, P. hypomelanus, P. lombocensis, P. ocularis, P. temminckii, and P. vampyrus) and 14 smaller fruit bats (Chironax melanocephalus, Cynopterus sp., Dobsonia sp., D. cf. peronii, D. moluccensis, D. viridis, Eonycteris spelaea, Macroglossus minimus, Nyctimene sp., Rousettus sp., R. amplexicaudatus, R. celebensis, R. linduensis, and Syconyteris australis) (Table S1). Members of three of flying fox taxa (A. celebensis, P. alecto, P. vampyrus) were recognized as belonging to multiple subspecies or found across a broad geographic range, and representative samples were taken from each established day roost. Habitats ranged from tracts of pristine mangrove forest to fragments of lightly disturbed secondary forest near human settlement. In addition, eight $P$. alecto fecal samples were collected in Central Sulawesi during 2012, and $91 P$. vampyrus fecal samples were collected from two sites in West Java during 2012-2013 (Table S2). 


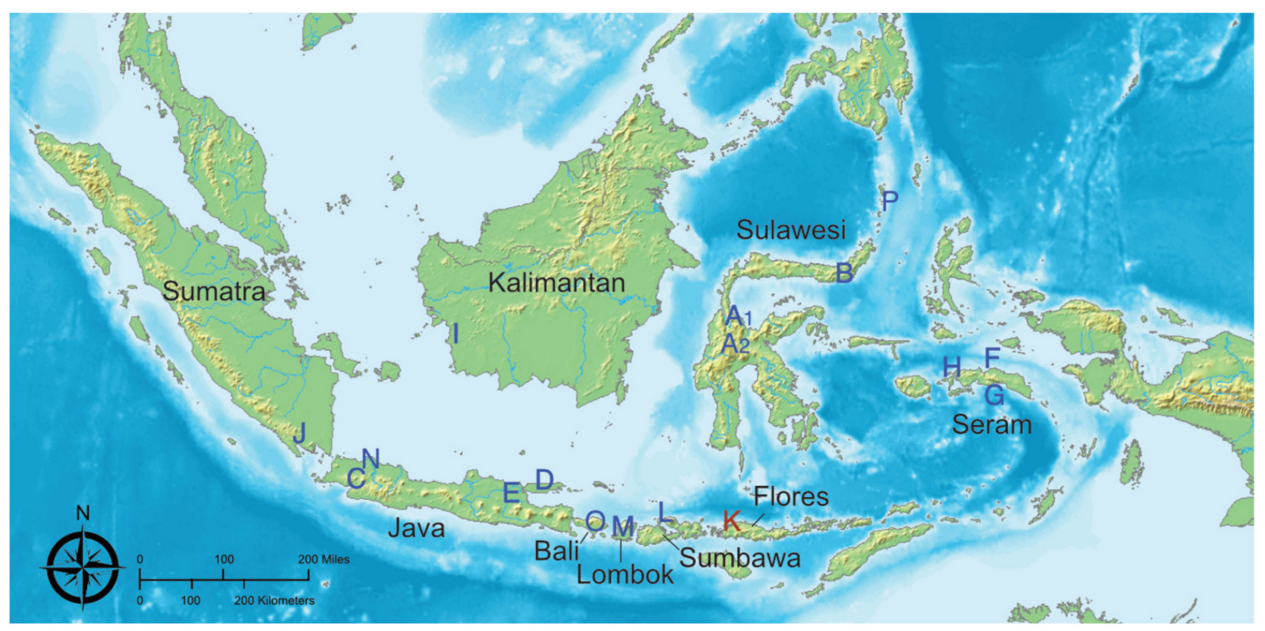

Figure 1. Locations of 17 sites across the Indonesian archipelago where tissues from pteropodid bats were sampled for viral screening. Location $\mathrm{K}$ is the site of the Pteropus vampyrus positive for Tioman virus.

Table 1. Bat species, province, site code (with reference letter on map), number of bats, and sample types tested for paramyxoviruses with a conventional RT-PCR.

\begin{tabular}{|c|c|c|c|c|c|c|c|c|c|}
\hline Species & $\begin{array}{l}\text { Sampling } \\
\text { Location }\end{array}$ & $\begin{array}{l}\text { Site } \\
\text { Code }\end{array}$ & $\begin{array}{l}\text { No. } \\
\text { bats }\end{array}$ & Kidney & Liver & Lung & $\begin{array}{c}\text { Oral } \\
\text { Swab }\end{array}$ & $\begin{array}{l}\text { Rectal } \\
\text { Swab }\end{array}$ & $\begin{array}{c}\text { Small } \\
\text { Intestine }\end{array}$ \\
\hline Acerodon celebensis & Central Sulawesi & A1 & 6 & - & 6 & - & - & 3 & - \\
\hline Acerodon celebensis & Gorontalo & $\mathrm{B}$ & 6 & - & 6 & 2 & 4 & 2 & - \\
\hline Acerodon mackloti & Lombok & M & 2 & 2 & 2 & 2 & 3 & 2 & 2 \\
\hline Chironax melanocephalus & Central Sulawesi & $\mathrm{A} 2$ & 1 & - & 1 & - & - & - & - \\
\hline Cynopterus sp. & Central Sulawesi & $\mathrm{A} 2$ & 5 & - & 4 & - & - & 2 & - \\
\hline Dobsonia cf. peronii & Lombok & $\mathrm{M}$ & 1 & - & - & - & 1 & 1 & - \\
\hline Dobsonia moluccensis & Maluku & $\mathrm{H}$ & 1 & - & 1 & - & - & - & - \\
\hline Dobsonia sp. & Seram, Maluku & G & 2 & - & 1 & - & 2 & 2 & - \\
\hline Dobsonia viridis & Maluku & $\mathrm{H}$ & 3 & - & 3 & - & - & 2 & - \\
\hline Eonycteris spelaea & West Kalimantan & I & 2 & - & 2 & - & - & - & - \\
\hline Macroglossus minimus & Central Sulawesi & $\mathrm{A} 2$ & 2 & - & 2 & - & - & 1 & - \\
\hline Macroglossus minimus & Seram, Maluku & $\mathrm{H}$ & 1 & - & 1 & - & - & - & - \\
\hline Nyctimene sp. & Seram, Maluku & $\mathrm{G}, \mathrm{H}$ & 6 & - & 2 & - & 4 & 4 & - \\
\hline Pteropus alecto & Central Sulawesi & A1 & 12 & - & 11 & 4 & 2 & 5 & - \\
\hline Pteropus alecto & Gorontalo & $\mathrm{B}$ & 4 & - & 4 & - & 2 & 1 & - \\
\hline Pteropus chrysoproctus & Seram, Maluku & $\mathrm{H}$ & 4 & 4 & 4 & 4 & 4 & 4 & 4 \\
\hline Pteropus hypomelanus & East Java & $\mathrm{E}$ & 3 & 2 & 2 & 2 & - & 3 & 2 \\
\hline Pteropus hypomelanus & Sangihe Islands & $\mathrm{P}$ & 3 & - & 3 & - & 3 & 2 & - \\
\hline Pteropus lombocensis & Lombok & M & 1 & 1 & 1 & 1 & 1 & 1 & 1 \\
\hline Pteropus ocularis & Seram, Maluku & $\mathrm{F}$ & 1 & 1 & 1 & 1 & 1 & 1 & 1 \\
\hline Pteropus temminckii & Seram Maluku & $\mathrm{F}, \mathrm{G}$ & 3 & 3 & 3 & 2 & 3 & 3 & 3 \\
\hline Pteropus vampyrus & Bali & $\mathrm{O}$ & 1 & - & - & - & 1 & 1 & - \\
\hline Pteropus vampyrus & East Java & $\mathrm{E}$ & 2 & 2 & 2 & 2 & 2 & 2 & 2 \\
\hline Pteropus vampyrus & Flores & $\mathrm{K}$ & 2 & 2 & 2 & 2 & 2 & 2 & 2 \\
\hline Pteropus vampyrus & South Sumatra & $\mathrm{J}$ & 2 & 2 & 2 & 2 & 2 & 2 & 2 \\
\hline Pteropus vampyrus & West Java & $\mathrm{C}$ & 4 & 1 & 4 & 2 & 4 & 4 & 1 \\
\hline Pteropus vampyrus & West Kalimantan & I & 2 & 2 & 2 & 2 & 2 & 2 & 2 \\
\hline Pteropus vampyrus & Sumbawa & $\mathrm{L}$ & 1 & 1 & 1 & 1 & 1 & 1 & 1 \\
\hline Rousettus amplexicaudatus & Seram, Maluku & $\mathrm{H}$ & 2 & - & 1 & - & 1 & 1 & - \\
\hline Rousettus celebensis & Central Sulawesi & $\mathrm{A} 2$ & 1 & - & 1 & - & - & - & - \\
\hline Rousettus linduensis & Central Sulawesi & $\mathrm{A} 2$ & 1 & - & 1 & - & - & - & - \\
\hline Rousettus sp. & Central Sulawesi & $\mathrm{A} 2$ & 4 & - & 3 & - & - & 2 & - \\
\hline Syconycteris australis & Seram, Maluku & $\mathrm{G}, \mathrm{H}$ & 4 & - & 2 & - & 2 & 3 & - \\
\hline Total & & & 95 & 23 & 81 & 29 & 47 & 59 & 23 \\
\hline
\end{tabular}


Samples were preserved in RNAlater (ThermoFisher, Waltham, MA, USA) and kept on wet ice until transfer to a $-20{ }^{\circ} \mathrm{C}$ freezer. Voucher specimens were preserved in the collections at the Museum Zoologicum Bogoriense at the Indonesian Institute of Sciences in Cibinong, Indonesia (Table S1). Bat capture, handling, and sampling methods were approved by the IACUC committee at City College of New York (Protocol No. 896.2 to D. J. Lohman and S. M. Tsang). Permission for research and fieldwork was granted by the Indonesian Ministry of Research and Technology/National Research and Innovation Agency (RISTEK-BRIN, formerly RISTEK) and the Ministry of Environment and Forestry.

\section{PCR, Next Generation Sequencing and Sequence Analysis}

Nucleic acids were extracted from bat tissues at the Australian Animal Health Laboratory in Geelong, Victoria. Carbide beads and 300-500 uL of AVL Buffer (Qiagen, Hilden, Germany) were added to each sample and these were homogenized in a Mini-Beadbeater (BioSpec, Bartlesville, OK, USA). The samples were centrifuged for 5 min at 13,000 rpm, and RNA was extracted from $180 \mu \mathrm{L}$ of the supernatant using a MagMax-96 Viral RNA Isolation Kit (ThermoFisher, Waltham, MA, USA) per the manufacturer's instructions. RNA was eluted into $50 \mu \mathrm{L}$ buffer and quantitated with a NanoDrop Spectrophotometer (ThermoFisher, Waltham, MA, USA) to confirm successful RNA extraction. RNA was stored at $-80^{\circ} \mathrm{C}$ until shipment to Duke-NUS Medical School for conventional PCR and Illumina sequencing. cDNA was synthesized from extracted tissue and feces RNA using Superscript III Reverse Transcriptase (Thermo-Fisher, Waltham, MA, USA) and screened for paramyxoviruses with a hemi-nested conventional PCR [12]. A paramyxovirus positive control plasmid was produced by ligating a PIV4B amplified PCR product into the pGEM $^{\circledR}$-T Easy Vector (Promega Corporation, Madison, WI, USA). The selected clone was validated by restriction digestion and PCR amplification, followed by expansion in maxi culture and purification (NucleoBond Maxi Plus EF, Macherey-Nagel, Düren, Germany) to produce a stock control.

Liver, lung, and kidney tissue samples from 43 bats were pooled based on species and location (Table S3). A total of $200 \mu \mathrm{L}$ of pooled materials from each set were extracted using Direct-zol $^{\text {TM }}$ RNA MiniPrep kit with TRI-Reagent (Zymo Research Corporation, Irvine, CA, USA) per manufacturer's instruction. RNA was subjected to in-column DNase I (New England BioLabs Inc., Ipswich, MA, USA) digestion as instructed in the Direct-zol ${ }^{\mathrm{TM}}$ RNA MiniPrep manual. Extracted and DNase I digested RNA were treated with Ribo-Zero ${ }^{\mathrm{TM}}$ Gold Epidemiology Kit (San Diego, CA, USA) following the manufacturer's protocol. Sequencing cDNA libraries of 260 bp were constructed using a TruSeq ${ }^{\circledR}$ RNA Exome kit (Illumina; San Diego, CA, USA) following the manufacturer's protocol. Library quality was assessed with an Agilent Bioanalyzer High Sensitivity DNA Assay and sequenced on an Illumina HiSeq2000 platform using a $76 \mathrm{bp}$ paired-end run.

FASTQ files were examined with FastQC to determine quality [23]. Trimming was performed with Trimmomatic-0.3.2 to remove adapters, low quality bases $(\mathrm{Q}=20$ with a sliding window of 4), and reads smaller than $50 \mathrm{bp}$ [24]. Taxonomic read classification was assigned with DIAMOND using a local National Center for Biotechnology Information (NCBI) $\mathrm{nr}$ (non-redundant) protein database [25]. DIAMOND outputs were processed to generate taxonomic classification with MEGAN6 using a naïve least common ancestor algorithm with a minimum score of 50, a max expected score of 0.01 and a top percent of 10 [26]. Paramyxovirus reads were exported, de novo assembled and mapped to a Tioman virus reference genome (NC_004074) in Geneious 11.1.2 (Biomatters Ltd., Auckland, New Zealand) [27]. A 729 basepair alignment was generated using MAFFT with representative L gene sequences from several paramyxoviruses downloaded from NCBI GenBank and two 101 bp reads from the NGS data [28]. Maximum likelihood phylogenetic analysis was performed using IQ-TREE [29]. The best-fit nucleotide substitution model was selected with ModelFinder using the Bayesian information criterion, and branch support was estimated using 2000 ultrafast bootstrap replicates [30]. To infer the robustness of the 
phylogeny, we performed a likelihood mapping analysis using IQ-TREE for the L gene sequence alignment, including members of the Rubulavirinae subfamily.

\section{Results/Discussion}

No paramyxovirus amplicons were generated in the fecal and tissue samples tested with the paramyxovirus PCR. Genomic evidence of Tioman virus was detected from a pooled kidney, liver and lung sample from a single Pteropus vampyrus individual from a small island northwest of Flores (Figure 1, site K). A total of 70,956,245 reads were generated from the NGS reaction (NCBI BioProject PRJNA693365). The majority of these reads were vertebrate in origin $(83.19 \%)$, while unassigned reads were the second most common $(9.37 \%)$. Virus reads comprised $0.01 \%(n=5048)$ of all reads (Table 2$)$.

Table 2. Next generation sequencing reads for the Pteropus vampyrus bat from Flores (Site K) with Tioman virus sequences. The predominant taxa in the fastq file are presented with the percentage of total reads.

\begin{tabular}{|c|c|c|c|c|c|}
\hline Taxon & Forward Unpaired Reads & Reverse Unpaired Reads & Forward Paired Reads & Reverse Paired Reads & Total \\
\hline Eukaryota & $4,569,303(78.7 \%)$ & $803,357(82.0 \%)$ & $27,331,682(85.3 \%)$ & $27,643,874(86.3 \%)$ & $60,348,216(85.0 \%)$ \\
\hline Vertebrata & $4,436,518(75.3 \%)$ & $788,376(80.5 \%)$ & $26,699,724(83.3 \%)$ & $27,103,904(84.6 \%)$ & $59,028,522(83.2 \%)$ \\
\hline Platyhelminthes & $5949(0.1 \%)$ & $111(<0.1 \%)$ & $28,122(<0.1 \%)$ & $5914(<0.1 \%)$ & $40,096(<0.1 \%)$ \\
\hline Bacteria & $93,262(1.6 \%)$ & $11,778(1.2 \%)$ & $516,241(1.6 \%)$ & $507,629(1.6 \%)$ & $1128,910(1.6 \%)$ \\
\hline Fungi & $76(<0.1 \%)$ & $5(<0.1 \%)$ & $392(<0.1 \%)$ & $355(<0.1 \%)$ & $828(<0.1 \%)$ \\
\hline Viruses & $446(<0.1 \%)$ & $79(<0.1 \%)$ & $2293(<0.1 \%)$ & $2230(<0.1 \%)$ & $5048(<0.1 \%)$ \\
\hline Herpesvirales & $3(<0.1 \%)$ & $0(0 \%)$ & $72(<0.1 \%)$ & $52(<0.1 \%)$ & $127(<0.1 \%)$ \\
\hline Retroviridae & $97(<0.1 \%)$ & $28(<0.1 \%)$ & $889(<0.1 \%)$ & $893(<0.1 \%)$ & $1907(<0.1 \%)$ \\
\hline Poxviridae & $2(<0.1 \%)$ & $1(<0.1 \%)$ & $16(<0.1 \%)$ & $16(<0.1 \%)$ & $35(<0.1 \%)$ \\
\hline Paramyxoviridae & $5(<0.1 \%)$ & $4(<0.1 \%)$ & $70(<0.1 \%)$ & $68(<0.1 \%)$ & $147(<0.1 \%)$ \\
\hline Not assigned & $1,011,911(17.2 \%)$ & $127,330(13.0 \%)$ & $2,916,552(9.1 \%)$ & $2,586,915(8.1 \%)$ & $6,645,708(9.4 \%)$ \\
\hline Total Reads & $5,890,265$ & 979,360 & $32,056,464$ & $32,030,156$ & $70,956,245$ \\
\hline
\end{tabular}

There were 147 paramyxovirus reads, and 143 of these mapped to the Tioman virus reference genome (Figure 2; Table S4). Across the Tioman virus reference genome (15,522 bp; NC_004074), NGS reads covered nearly half the genome ( $44.3 \%, 6879 \mathrm{bp})$ with a nucleotide pairwise identity of $98.5 \%$ and a depth of 1-8 nucleotides. There were reads for each gene, including the nucleocapsid gene (41\%), phosphoprotein gene $(55.1 \%)$, matrix gene $(36.8 \%)$, fusion gene $(35.1 \%)$, hemagglutinin and neuraminidase gene $(39.2 \%)$, and the polymerase (L) gene $(50.2 \%)$. The sequence reads from the P. vampyrus formed a monophyletic clade with Tioman virus $L$ gene sequences previously collected from Malaysia and India (bootstrap value $=80$ ). However, the Indonesian sequence was most closely related to viral sequences from a P. hypomelanus specimen in Malaysia. Additionally, the L gene sequence of Tioman viruses clustered most closely with other Pararubulavirus sequences collected from Pteropus species across multiple continents (Figure 3). The likelihood mapping shows that the dataset contains a reasonable amount of tree-likeness as the edges comprise $>75 \%$ of the values. A bootstrap analysis supported these conclusions with reasonably high support for most nodes (Figure S1).

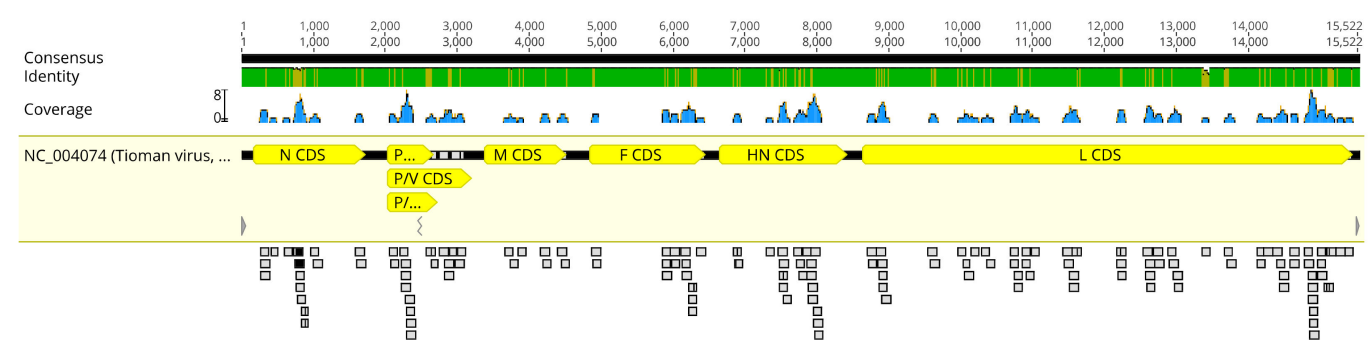

Figure 2. Coverage of next generation sequencing reads from a Pteropus vampyrus assembled to a reference genome of Tioman virus (Accession number: NC_004074). Coverage ranged from 0-8 nucleotides across the genome, represented in blue above the annotated reference genome. 


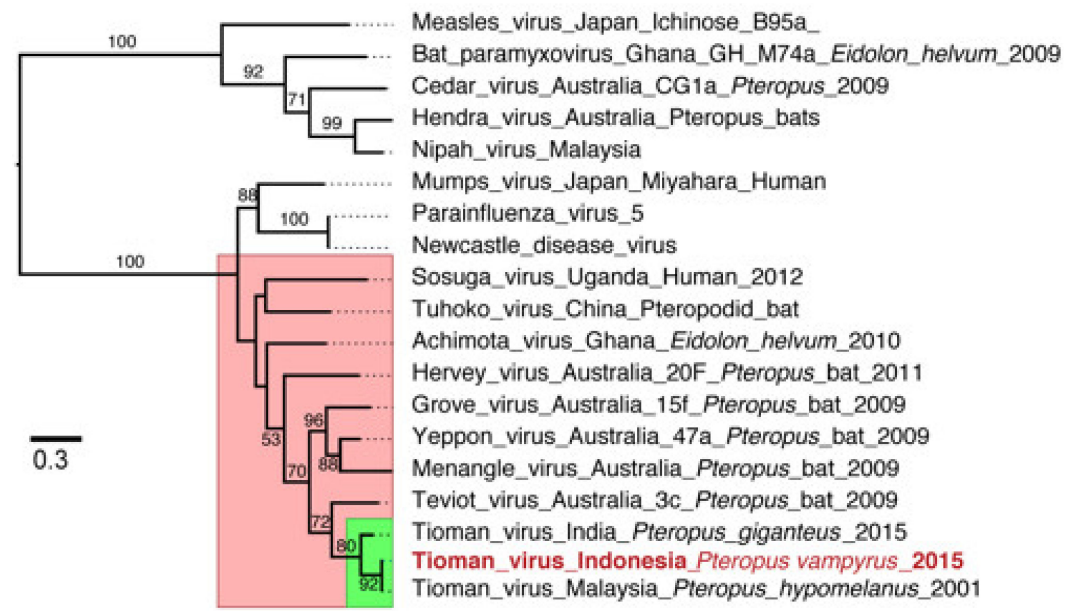

Figure 3. Maximum likelihood phylogeny of the $\mathrm{L}$ (polymerase) gene region of paramyxoviruses. The red box denotes sequences from members of the genus Pararubulavirus and the green box indicates Tioman virus sequences. Bootstrap values $>50 \%$ are indicated at branch nodes. The scale bar represents the nucleotide substitutions per site.

Tioman virus was first detected in Malaysia on Tioman Island in 2001 during surveillance efforts to detect Nipah virus [15]. This virus was isolated on Vero cells from urine samples from Pteropus hypomelanus resulting in cytopathic effect including syncytia. It was confirmed to be a new virus through sequencing and phylogenetic analysis. It is unknown if Tioman virus is pathogenic in humans; however, there is evidence of seroreactivity in humans on Tioman Island (1.8\% tested seropositive) [31]. Experimental infections in pigs caused fever and generated neutralizing antibodies, suggesting that they could act as intermediate reservoirs [32]. This genus includes Menangle pararubulavirus and Sosuga pararubulavirus, which are both pathogenic to humans [33].

Evidence of Tioman virus infection in bats has now been detected in six countries. Species in the genus Pteropus, the natural reservoir, range from Oceania, through Australia and tropical/subtropical Asia, to Madagascar [22]. A study in Madagascar detected antibodies against Tioman virus in two out of 349 Pteropus rufus tested $(0.57 \%)$ and in one additional pteropodid bat (Rousettus madagascariensis) [34]. Tioman virus was isolated from kidney tissue of a single P. giganteus individual (1.5\% of bats screened) captured in Assam, India [35]. In New Guinea, sera from 66 P. conspicillatus bats were tested for Tioman virus-specific antibodies, and 38\% were seropositive [36]. A recent survey in Adelaide, Australia, detected serological evidence of Tioman virus in P. poliocephalus [37]. Henipavirus outbreaks and exposure in humans or other animal hosts are concordant with the distribution of their bat reservoirs; however, there is no evidence of previous bat-borne paramyxovirus outbreaks in Indonesia [38]. Our detection of this virus in the Indonesian Archipelago affirms that this virus is likely endemic in Pteropus across the genus' distribution, though questions remain about its endemicity to Australia and the islands of the Pacific.

The remote island northeast of Flores on which the Tioman virus-infected individual was found is a new locality record for Pteropus vampyrus, thus expanding the bat's known range [19]. The phylogenetic distinctiveness of this population suggests lack of recent gene flow with populations on Flores or other islands of the Lesser Sundas [19]. Presence of the virus in such an isolated population suggests that it was likely endemic in the $P$. vampyrus that founded the island's population. The day roost is within a conservation area on an offshore island with a dense mangrove swamp forest and few beaches. The rugged terrain and the presence of multiple, large $(\sim 3 \mathrm{~m})$ Komodo dragons (Varanus komodoensis) likely act as a deterrent to hunting or long-term human settlement. These factors may have helped promote population growth and stability, with over 5000 individuals located at a single site. This situation stands in stark contrast to western Indonesian roosts that contend 
with human settlements and occupy any suitable tree in disturbed landscapes, resulting in spatial fragmentation of large colonies [19].

The relative isolation and apparent stability of the Flores colony combined with its large population size are both likely key contributing factors that promote sustained bat-tobat transmission of Tioman virus. Isolation on islands often results in ecological feedback that leads to decreased influence from interspecific interactions, but increased influence from intraspecific interactions [39]. Tioman virus might be maintained in this isolated population because bat immunological responses to infection can aid viral persistence, while the annual addition of immunologically naïve pups would allow for sustained transmission within the colony without the need for external introduction from immigrating individuals [40,41]. The paramyxovirus family-specific primers did not detect the virus, indicating that there may have been low amounts of viral DNA in extracts of bat tissues. Increasing viral surveillance may lead to additional viral discovery; there are likely several undiscovered paramyxovirus lineages circulating in bat reservoir hosts across unsampled colonies in Indonesia. Poor knowledge of bat foraging ranges and migration coupled with the difficulty of reaching remote colonies stressed by hunting pressures makes routine surveillance challenging.

Supplementary Materials: The following are available online at https:/ /www.mdpi.com/article/ 10.3390/v13040563/s1. Table S1: Species and sample list for conventional PCR screening. Table S2: Museum voucher numbers of bat samples. Table S3: Species and sample list for next generation sequencing libraries. Table S4: Tioman virus sequences by gene from next generation sequencing data. Figure S1: Likelihood mapping for the Rubulavirinae dataset comprising 14 sequences of $729 \mathrm{bp}$.

Author Contributions: Conceptualization, S.M.T., S.W., D.V., D.J.L., and I.H.M.; sample collection, S.M.T. and S.W.; laboratory work, I.S. and D.H.W.L.; analysis, D.H.W.L., J.J., D.V., and I.H.M.; writing—original draft preparation, S.M.T., D.H.W.L., and I.H.M.; writing-review and editing, S.M.T., D.H.W.L., I.S., S.W., N.B.S., D.V., D.J.L., and I.H.M.; funding acquisition, S.M.T., D.V., N.B.S., and D.J.L. All authors have read and agreed to the published version of the manuscript.

Funding: This work was funded by a National Geographic Young Explorers Grant (9272-13) to S.M.T., American Philosophical Society Lewis and Clark Fund for Exploration Award to S.M.T., Fulbright Indonesia Research Fellowship to S.M.T., and NIH grant R21 AI105050-01 to D.J.L., N.B.S., and V.D.

Institutional Review Board Statement: The Ministry of Environment and Forestry, RISTEK-BRIN (formerly RISTEK) and local government entities granted permission and collection permits (1337/FRP/ SM/IV/2012, 387/SIP/FRP/SM/IX/2012, 396/FRP/SM/II/2014) that made fieldwork and export possible, and specimens were imported with USFWS, CDC, and CITES permits. Bat capture, handling, and sampling protocols were approved by the IACUC committee at City College of New York (Protocol No. 896.2 to D.J.L. and S.M.T.).

Informed Consent Statement: Not applicable.

Data Availability Statement: Supporting data can be found at the NCBI BioProject PRJNA693365.

Acknowledgments: We are indebted to Abdul Rahman, the late Edy Toyibi, Sheherazade, Yusep Synata, and the staff of BKSDA and the protected areas where we sampled for assistance in the field. Memoranda of Understanding between the City College of New York (CCNY) and the Museum Zoologicum Bogoriense facilitated collaborative field expeditions in Indonesia. We are grateful to Rudolf Meier, who hosted SMT with funding from an NSF EAPSI Fellowship (OISE-1108298).

Conflicts of Interest: The authors declare no conflict of interest.

\section{References}

1. Irving, A.T.; Ahn, M.; Goh, G.; Anderson, D.E.; Wang, L.F. Lessons from the host defenses of bats, a unique viral reservoir. Nature 2021, 589, 363-370. [CrossRef] [PubMed]

2. Calisher, C.H.; Childs, J.E.; Field, H.E.; Holmes, K.V.; Schountz, T. Bats: Important reservoir hosts of emerging viruses. Clin. Micro. Rev. 2006, 19, 531-545. [CrossRef]

3. Hutson, A.M.; Mickleburgh, S.P. Microchiropteran Bats: Global Status Survey and Conservation Action Plan; IUCN: Cambridge, UK, 2001; Volume 56. 
4. Kunz, T.H.; Fenton, M.B. Bat Ecology; University of Chicago Press: Chicago, IL, USA, 2005.

5. Hayman, D.T. Bats as viral reservoirs. Annu. Rev. Virol. 2016, 3, 77-99. [CrossRef] [PubMed]

6. Allen, T.; Murray, K.A.; Zambrana-Torrelio, C.; Morse, S.S.; Rondinini, C.; Di Marco, M.; Breit, N.; Olival, K.J.; Daszak, P. Global hotspots and correlates of emerging zoonotic diseases. Nat. Commun. 2017, 8, 1124. [CrossRef]

7. Plowright, R.K.; Foley, P.; Field, H.E.; Dobson, A.P.; Foley, J.E.; Eby, P.; Daszak, P. Urban habituation, ecological connectivity and epidemic dampening: The emergence of Hendra virus from flying foxes (Pteropus spp.). Proc. R. Soc. B 2011, $278,3703-3712$. [CrossRef]

8. Jones, B.A.; Grace, D.; Kock, R.; Alonso, S.; Rushton, J.; Said, M.Y.; McKeever, D.; Mutua, F.; Young, J.; McDermott, J. Zoonosis emergence linked to agricultural intensification and environmental change. Proc. Natl. Acad. Sci. USA 2013, 110, 8399-8404. [CrossRef]

9. Voigt, C.C.; Kingston, T. Bats in the Anthropocene: Conservation of Bats in a Changing World; Springer Science+ Business Media: Cham, Switzerland, 2016.

10. Drexler, J.F.; Corman, V.M.; Muller, M.A.; Maganga, G.D.; Vallo, P.; Binger, T.; Gloza-Rausch, F.; Cottontail, V.M.; Rasche, A.; Yordanov, S.; et al. Bats host major mammalian paramyxoviruses. Nat. Commun. 2012, 3, 796. [CrossRef] [PubMed]

11. Rima, B.; Balkema-Buschmann, A.; Dundon, W.G.; Duprex, P.; Easton, A.; Fouchier, R.; Kurath, G.; Lamb, R.; Lee, B.; Rota, P. ICTV Virus Taxonomy Profile: Paramyxoviridae. J. Gen. Virol. 2019, 100, 1593-1594. [CrossRef]

12. Tong, S.; Chern, S.W.; Li, Y.; Pallansch, M.A.; Anderson, L.J. Sensitive and broadly reactive reverse transcription-PCR assays to detect novel paramyxoviruses. J. Clin. Microbiol. 2008, 46, 2652-2658. [CrossRef]

13. Anderson, D.E.; Wang, L.-F. New and emerging paramyxoviruses. In The Biology of Paramyxoviruses; Caister Academic Press: Norfolk, UK, 2011; pp. 435-459.

14. Barr, J.; Smith, C.; Smith, I.; de Jong, C.; Todd, S.; Melville, D.; Broos, A.; Crameri, S.; Haining, J.; Marsh, G.; et al. Isolation of multiple novel paramyxoviruses from pteropid bat urine. J. Gen. Virol. 2015, 96, 24-29. [CrossRef]

15. Chua, K.B.; Wang, L.F.; Lam, S.K.; Crameri, G.; Yu, M.; Wise, T.; Boyle, D.; Hyatt, A.D.; Eaton, B.T. Tioman virus, a novel paramyxovirus isolated from fruit bats in Malaysia. Virology 2001, 283, 215-229. [CrossRef]

16. Simmons, N.; Cirranello, A. Bat Species of the World: A Taxonomic and Geographic Database. Available online: https: / / batnames.org (accessed on 15 March 2021).

17. Arevalo, R.L.M.; Amador, L.I.; Almeida, F.C.; Giannini, N.P. Evolution of body mass in bats: Insights from a large supermatrix phylogeny. J. Mamm. Evol. 2020, 27, 123-138. [CrossRef]

18. Tsang, S.M.; Wiantoro, S. Indonesian flying foxes: Research and conservation status update. Trebuia 2019, 46, 103-113. [CrossRef]

19. Tsang, S.M.; Wiantoro, S.; Veluz, M.J.; Simmons, N.B.; Lohman, D.J. Low levels of population structure among geographically distant populations of Pteropus vampyrus (Chiroptera: Pteropodidae). Acta Chiropt. 2018, 20, 59-71. [CrossRef]

20. Tsang, S.M.; Wiantoro, S.; Simmons, N.B. New records of flying foxes (Chiroptera: Pteropus sp.) from Seram, Indonesia, with notes on ecology and conservation status. Am. Mus. Novit. 2015, 3842, 1-23. [CrossRef]

21. Eaton, B.T.; Broder, C.C.; Middleton, D.; Wang, L.-F. Hendra and Nipah viruses: Different and dangerous. Nat. Rev. Microbiol. 2006, 4, 23-35. [CrossRef]

22. Tsang, S.M.; Wiantoro, S.; Veluz, M.J.; Sugita, N.; Nguyen, Y.L.; Simmons, N.B.; Lohman, D.J. Dispersal out of Wallacea spurs diversification of Pteropus flying foxes, the world's largest bats (Mammalia: Chiroptera). J. Biogeogr. 2020, 47, 527-537. [CrossRef]

23. Andrews, S. FastQC: A Quality Control Tool for High Throughput Sequence Data; Babraham Bioinformatics, Babraham Institute: Cambridge, UK, 2010.

24. Bolger, A.M.; Lohse, M.; Usadel, B. Trimmomatic: A flexible trimmer for Illumina sequence data. Bioinformatics 2014, 30, 2114-2120. [CrossRef] [PubMed]

25. Buchfink, B.; Xie, C.; Huson, D.H. Fast and sensitive protein alignment using DIAMOND. Nat. Methods 2015, 12, 59-60. [CrossRef] [PubMed]

26. Huson, D.H.; Beier, S.; Flade, I.; Gorska, A.; El-Hadidi, M.; Mitra, S.; Ruscheweyh, H.J.; Tappu, R. MEGAN Community Edition -Interactive exploration and analysis of large-scale microbiome sequencing data. PLoS Comput. Biol. 2016, 12, e1004957. [CrossRef]

27. Kearse, M.; Moir, R.; Wilson, A.; Stones-Havas, S.; Cheung, M.; Sturrock, S.; Buxton, S.; Cooper, A.; Markowitz, S.; Duran, C.; et al. Geneious Basic: An integrated and extendable desktop software platform for the organization and analysis of sequence data. Bioinformatics 2012, 28, 1647-1649. [CrossRef]

28. Katoh, K.; Standley, D.M. MAFFT multiple sequence alignment software version 7: Improvements in performance and usability. Mol. Biol. Evol. 2013, 30, 772-780. [CrossRef]

29. Nguyen, L.-T.; Schmidt, H.A.; Von Haeseler, A.; Minh, B.Q. IQ-TREE: A fast and effective stochastic algorithm for estimating maximum-likelihood phylogenies. Mol. Biol. Evol. 2015, 32, 268-274. [CrossRef]

30. Kalyaanamoorthy, S.; Minh, B.Q.; Wong, T.K.; von Haeseler, A.; Jermiin, L.S. ModelFinder: Fast model selection for accurate phylogenetic estimates. Nat. Methods 2017, 14, 587-589. [CrossRef] [PubMed]

31. Yaiw, K.C.; Crameri, G.; Wang, L.; Chong, H.T.; Chua, K.B.; Tan, C.T.; Goh, K.J.; Shamala, D.; Wong, K.T. Serological evidence of possible human infection with Tioman virus, a newly described paramyxovirus of bat origin. J. Infect. Dis. 2007, 196, 884-886. [CrossRef] [PubMed] 
32. Yaiw, K.C.; Bingham, J.; Crameri, G.; Mungall, B.; Hyatt, A.; Yu, M.; Eaton, B.; Shamala, D.; Wang, L.F.; Thong Wong, K. Tioman virus, a paramyxovirus of bat origin, causes mild disease in pigs and has a predilection for lymphoid tissues. J. Virol. 2008, 82, 565-568. [CrossRef]

33. Anderson, D.E.; Marsh, G.A. Bat paramyxoviruses. In Bats and Viruses; John Wiley \& Sons, Inc.: Hoboken, NJ, USA, 2015; pp. 99-126.

34. Iehle, C.; Razafitrimo, G.; Razainirina, J.; Andriaholinirina, N.; Goodman, S.M.; Faure, C.; Georges-Courbot, M.C.; Rousset, D.; Reynes, J.M. Henipavirus and Tioman virus antibodies in pteropodid bats, Madagascar. Emerg. Infect. Dis. 2007, 13, 159-161. [CrossRef] [PubMed]

35. Yadav, P.; Sarkale, P.; Patil, D.; Shete, A.; Kokate, P.; Kumar, V.; Jain, R.; Jadhav, S.; Basu, A.; Pawar, S. Isolation of Tioman virus from Pteropus giganteus bat in North-East region of India. Infect. Genet. Evol. 2016, 45, 224-229. [CrossRef]

36. Breed, A.C.; Yu, M.; Barr, J.A.; Crameri, G.; Thalmann, C.M.; Wang, L.-F. Prevalence of henipavirus and rubulavirus antibodies in pteropid bats, Papua New Guinea. Emerg. Infect. Dis. 2010, 16, 1997. [CrossRef] [PubMed]

37. Boardman, W.S.; Baker, M.L.; Boyd, V.; Crameri, G.; Peck, G.R.; Reardon, T.; Smith, I.G.; Caraguel, C.G.; Prowse, T.A. Seroprevalence of three paramyxoviruses; Hendra virus, Tioman virus, Cedar virus and a rhabdovirus, Australian bat lyssavirus, in a range expanding fruit bat, the Grey-headed flying fox (Pteropus poliocephalus). PLoS ONE 2020, 15, e0232339. [CrossRef]

38. Marsh, G.A.; Wang, L.-F. Henipaviruses: Deadly zoonotic paramyxoviruses of bat origin. In The Role of Animals in Emerging Viral Diseases; Elsevier: Amsterdam, The Netherlands, 2014; pp. 125-142.

39. Lomolino, M.V. The unifying, fundamental principles of biogeography: Understanding island life. Front. Biogeogr. 2016, 8, e29920. [CrossRef]

40. Peel, A.J.; Baker, K.S.; Hayman, D.T.; Broder, C.C.; Cunningham, A.A.; Fooks, A.R.; Garnier, R.; Wood, J.L.; Restif, O. Support for viral persistence in bats from age-specific serology and models of maternal immunity. Sci. Rep. 2018, 8, 1-11.

41. Subudhi, S.; Rapin, N.; Misra, V. Immune system modulation and viral persistence in bats: Understanding viral spillover. Viruses 2019, 11, 192. [CrossRef] [PubMed] 